Rowan University

Rowan Digital Works

\title{
Qualitative research within the Deaf community in Northern Ireland: A multilingual approach
}

Brent C. Elder

Rowan University, elderb@rowan.edu

Michael A. Schwartz

Follow this and additional works at: https://rdw.rowan.edu/education_facpub

Part of the Disability and Equity in Education Commons

\section{Recommended Citation}

Elder, B. \& Schwartz, M. (2021). Qualitative research within the Deaf community in Northern Ireland: A multilingual approach. ALTER (in press).

This Article is brought to you for free and open access by the College of Education at Rowan Digital Works. It has been accepted for inclusion in College of Education Faculty Scholarship by an authorized administrator of Rowan Digital Works. 


\title{
Qualitative research within the Deaf community in Northern Ireland: A multilingual approach
}

\section{Recherche qualitative au sein de la communauté Sourde d'Irlande du Nord : une approche multilingue}

\author{
Brent C. Elder ${ }^{\mathrm{a}, *}$, Michael A. Schwartz ${ }^{\mathrm{b}}$ \\ a Department of Interdisciplinary and Inclusive Education, Rowan University, James Hall, 201 Mullica Hill \\ Rd, Glassboro, NJ 08028, USA \\ b Syracuse University, College of Law, Wohl Clinic Suite 200J, 950 Irving Avenue, Syracuse, NY 13244, USA
}

\section{A R T I C L E I N F O}

\section{Article history:}

Received 23 March 2020

Accepted $1^{\text {st }}$ April 2021

Available online $\mathrm{xxx}$

\section{Keywords:}

Community-based participatory research

(CBPR)

Deaf studies

Disability studies

Sign language

International qualitative research

Deaf access to justice

\begin{abstract}
A B S T R A C T
In this methodology article, the authors illustrate how they conducted multilingual qualitative research in an exploration of the barriers that Deaf people in Northern Ireland face when attempting to access the system of justice. The authors' research practices are informed, to the extent possible, by the principles of communitybased participatory research (CBPR). They explore the challenges of conducting research in American Sign Language (ASL), British Sign Language (BSL), and Irish Sign Language (ISL), and spoken English, facilitated by sign language interpreters fluent in BSL and ISL. Centering the research on the lived experiences of Deaf people who navigate the system of justice, the authors implemented CBPR-informed research methods, which ultimately led to sustained discussion and joint action by the authors and members of the Northern Ireland Deaf community aimed at the removal of barriers that Deaf people face when interacting with the justice system. By writing about their methodological approach in Northern Ireland, the authors wish to be transparent about their work in
\end{abstract}

\footnotetext{
* Corresponding author.

E-mail addresses: elderb@rowan.edu (B.C. Elder), maschw01@law.syr.edu (M.A. Schwartz).
} 
the hope that other researchers can replicate their successes and avoid the limitations of conducting this work in partnership with members of the Deaf community in other countries.

Published by Elsevier Masson SAS. All rights reserved.

\section{R É S U M É}

Mots clés :

Recherche participative basée sur la communauté (CBPR)

Études sur les sourds

Études sur les handicaps

Langage des signes

recherche qualitative internationale

Accès des Sourds à la justice
Dans cet article méthodologique, les auteurs reviennent sur la manière dont ils ont conduit une recherche qualitative multilingue consistant à explorer les barrières rencontrées par les personnes Sourdes en Ireland du Nord lorsqu'elles cherchent à avoir accès au système judiciaire. Dans la mesure du possible, les pratiques de recherche des auteurs ont respecté les principes d'une recherche participative prenant appui sur la communauté (CBPR). Ils explorent les défis d'une recherche réalisée en langue des signes américaine (ASL), britannique (BSL) et irlandaise (ISL), en anglais parlé ou avec l'aide d'interprètes ayant la maîtrise de la langue des signes britannique et irlandaise. Centrant la recherche sur les expériences des Sourds qui apprennent à circuler dans le système judiciaire, les auteurs ont mis en place des méthodes de recherche participatives et prenant appui sur la communauté. Celles-ci ont conduit à une discussion soutenue et une action conjointe avec les auteurs et les membres de la communauté Sourde d'Irlande du Nord visant à lever les barrières auxquelles les personnes Sourdes font face lorsqu'elles interagissent avec le système judiciaire. En présentant l'approche méthodologique adoptée en Ireland du Nord, les auteurs souhaitent présenter de manière transparente leur démarche dans l'espoir que d'autres chercheurs pourront reproduire ce qui a le mieux fonctionné et éviter les obstacles qui ont été rencontrés dans la conduite d'un travail en partenariat avec les membres de la communauté Sourde dans d'autres pays.

Publié par Elsevier Masson SAS. Tous droits réservés.

\section{Introduction}

Through this methodology article, two American authors, one hearing (Elder) and one Deaf (Schwartz), illustrate how they conducted multilingual qualitative research with Deaf participants in Northern Ireland. The subject of the research is the Deaf community's access to the system of justice in Northern Ireland. According to Article 13 of the United Nations Convention on the Rights of Persons with Disabilities (UNCRPD, 2006),

States Parties shall ensure effective access to justice for persons with disabilities on an equal basis with others, including through the provision of procedural and age-appropriate accommodations, in order to facilitate their effective role as direct and indirect participants, including as witnesses, in all legal proceedings, including at investigative and other preliminary stages ${ }^{1}$.

Additionally, this work is also framed by the United Kingdom's Disability Discrimination Act (DDA) (1995:Part 7B, Section 1b) that states that if a policy or practice of a solicitor or barrister places the disabled person at a substantial disadvantage in comparison with nondisabled people, the solicitor or barrister must "take such steps as it is reasonable, in all the circumstances of the case, for him to have to take in order to prevent the provision, criterion or practice, or feature, having that effect." While the

\footnotetext{
${ }^{1}$ As part of the United Kingdom which ratified the UNCRPD on June 8, 2009, Northern Ireland is obligated to comply with the terms of the UNCRPD.
} 
authors were informed by the principles of community-based participatory research (CBPR), which stresses the importance of including the Deaf participants in the research project, the authors, both American-born, were confronted by numerous methodological multilingual complexities during the exploration of Deaf access to the justice system in Northern Ireland. This article shifts through these complexities.

At the outset, the authors wish to clarify that the use of uppercase "D" indicates Deafness as a cultural phenomenon whereas the use of lower case "d" indicates deafness as a medical condition (Elder \& Schwartz, 2018; Woodward, 1972). Similarly, by using the word "Deaf," the authors wish to acknowledge the myriad ways that deafness intersects with various contexts and identities including, but not limited to, race, class, gender, age, and sexual orientation. The authors also want to point out that deafness includes a spectrum that encompasses a range of hearing loss, from the mildly hard of hearing to the profoundly deaf. Additionally, this spectrum includes people who use a variety of communication methods (e.g., spoken, unsigned) that may or may not include the use of sign language. By using the terms "Deaf" or "deaf," whichever is applicable, the authors intend to highlight the difference between the medical and social models of disability (Schwartz \& Elder, 2018). The authors also wish to include in this project everyone who has a hearing loss and needs accommodation to access the system of justice.

In this research project, the authors aim to highlight the multilingual complexities they negotiated conducting research in American Sign Language (ASL), British Sign Language (BSL), and Irish Sign Language (ISL), while involving interpreters fluent in BSL and ISL, and while Elder used spoken English. ASL, BSL, and ISL are distinctly different sign languages, and fluency in one does not automatically translate to fluency in the other (Elder \& Schwartz, 2018; Schwartz \& Elder, 2018; Symington \& Carberry, 2006). Throughout this paper, the authors discuss oppression and marginalization of Deaf people based on the condition of hearing loss and the utilization of sign language as a means of communication. The authors believe that Deaf people around the world can benefit from participating in research that centers on their lived experience of deafness and their systemic exclusion from the system of justice. Thus, the CBPR-informed research methods the authors used in this project focused on the lived experiences of Deaf people as they negotiated various barriers in attempting to access the justice system in Northern Ireland. With this work, the authors hope to start a conversation between Deaf and hearing research partners in other countries, and to share research methods that are aimed at creating opportunities for greater access to justice and potentially other inaccessible spheres of society (e.g., education, healthcare, recreation).

This paper is a culmination of three iterations of research in Northern Ireland that began in 2016, was extended in 2017, and at the time of writing, through a United Kingdom (UK) government grant through 2020. For more detailed information on the timeline of the projects, see Section 3.3 Timeline below. In these first two iterations, the authors interviewed Deaf people who had experienced barriers when attempting to access the justice system. Major findings of these research iterations included: (a) Deaf people experience many barriers within the justice system; (b) the legal concept of "reasonable adjustment" in determining the scope of an accommodation for a Deaf person is contested; (c) the key stakeholders in the system of justice need training in Deaf cultural awareness; and, (d) Deaf people engage in various forms of advocacy in order to gain appropriate access to justice (Byrne, Elder, \& Schwartz, 2021; Elder \& Schwartz, 2018; Schwartz \& Elder, 2018).

\section{Theoretical framework}

\subsection{Deaf studies}

Deaf studies, a discipline that intersects with anthropology, economics, geography, history, political science, psychology, social studies, and sociology, focuses on Deaf culture, the Deaf community, and the social life of a distinct minority intimately linked with the language of signs. Indeed, central to Deaf studies is the idea of "Deafhood," a broad ontological concept as well as a liberating, empowering narrative responding to hegemonic oralist and colonizing discourses (Kusters \& De Meulder, 2013; Ladd, 2003, 2005). As Kusters and De Meulder (2013:436) argue, “A better understanding of [Deafhood] 
will foster individual and collective self-determination among Deaf communities and will enhance academic discourses not only in Deaf studies but in other social sciences."

In their seminal book, Approaches to Social Research: The Case of Deaf Studies, Alys Young and Temple (2014) explore the relationship between key methodological debates in social research and the special context of studies concerning Deaf people. Their book focuses on deafness as a site of contested identity and representation; the epistemology of deafness; ethics in research involving deaf people; narrative methodologies in relation to the visual nature of signed languages; and, interpretation, translation and transcription of interviews. Young and Temple (2014) also show how social research provides challenges to established ways of thinking and working with Deaf people. This book helped guide the authors in thinking about, and conducting, their research in Northern Ireland.

Society has for centuries treated Deaf people as people in a state of pathology, as "biologically deficient beings in need of cures or charity in order to be successfully assimilated into society" (Ladd, 2005:12). The concept of colonialism most appropriately describes the "existential" reality of deaf communities, which contend with the hegemonic practices of oralism, and in rejecting colonial practices. Recent confirmation of the existence of bona-fide deaf cultures highlights the extent to which these communities have resisted majoritarian rule, maintaining their own beliefs concerning their validity and quality of their existence, and what they offer to non-deaf societies (Ladd, 2005). This "vulnerability as strength" is manifested through the concept of Deafhood, which is presented as a move towards a formal narrative of decolonizing and liberatory possibilities. Similarly, the notion of "Deaf gain" is particularly important here as it frames deafness as "a form of sensory and cognitive diversity that has the potential to contribute to the greater good of humanity" (Bauman \& Murray, 2009:3).

Despite the efforts by Deaf studies scholars to demonstrate the validity and vibrancy of the Deaf community, which has developed its own culture based on sign language, most countries treat their Deaf citizens as people with a disability. These governments implement policies that favor disability benefits, cochlear implants and mainstream education (Batterbury, 2012). By defining deafness as a medical condition rather than a social and cultural phenomenon, the state fails to implement language policies that would foster the native sign language of the country by recognizing its status as a language, which, by the way, is required by the UNCRPD (2006). The UNCRPD adopts a human rights approach requiring State Parties to the Convention to recognize a country's sign language and to support bilingual education for Deaf children. The hope of Deaf studies scholars is that the UNCRPD's regulatory context will encourage a shift in policy discourse about sign language that recognizes its primacy and value in the life of the Deaf community (Kusters, De Meulder, Friedner, \& Emery, 2015).

Also problematic for Deaf people is the idea of citizenship based on a spoken language, for example, in English, where "normative definitions of citizenship are inadequate to effectively encapsulate Deaf citizens' experience" (Emery, 2006:1). In particular, the phonocentric character of citizenship leaves Deaf citizens in perpetual disadvantage because the native language of the Deaf community is visual, not spoken, and a process of renegotiation is necessary in the policy arena to begin to adequately reflect Deaf peoples' experiences as citizens of a country, albeit with a different language (Emery, 2006). An idea formed in the crucible of Deaf studies is the characterization of the Deaf community as Sign Language Peoples (SLP), a term used by the World Federation of the Deaf and the UNCRPD (Solvang \& Haualand, 2014). The term expresses the idea that sign language reflects the diversity of human communication worthy of respect and protection.

\subsection{Disability studies}

In addition to deaf studies, the authors' research is also grounded in the academic field of Disability Studies. Several foundational principles of Disability Studies guide the authors. One, Disability Studies scholars privilege the narratives and lived experience of people with disabilities (Ferguson \& Nusbaum, 2012), including those who are deaf or hard of hearing. The Disability Studies lens teaches us that the participants' stories are central to the unfolding research. Two, Disability Studies aims to create an emancipatory narrative, one that reflects active subjects in charge of their lives (Mercer, 2002). Three, CBPR, a fundamental research approach organic to Disability Studies, aims to redistribute power from the center to the margins of society by privileging these narratives in the research (Hooks, 
1989; McCarthy, 1998). Four, Disability Studies illuminates how people who are deaf or hard of hearing are marginalized by oppressive practices, policies and procedures of systems that regulate social relations (Baglieri, Valle, Connor, \& Gallagher, 2011). The interaction between the center and the margins - oppression giving rise to resistance and counternarrative-is at the heart of Disability Studies. Finally, the authors view deafness and disability as a natural aspect of human diversity (Baglieri et al., 2011; Hehir, 2002; Linton, 2005, 2006; Shapiro, 1999).

As Disability Studies scholars, the authors believe that instead of being solely located in the body, disability represents the intersection between the physical condition of deafness and social practices (e.g., not providing an interpreter during legal proceedings). In other words, what is disabling is not the physical condition of a person but rather society's failure to accommodate human difference. Indeed, this social failure does not receive sufficient criticism (McDonnell, 2016). For instance, many Deaf people do not consider deafness a disability. Rather, they believe they become disabled when they interact with inaccessible spaces in society (e.g., a television without captions, people who do not know sign language, an event lacking sign language interpreters) (Padden \& Humphries, 1990, 2009). These tensions between what it means to claim a Deaf identity rather than a disabled one, despite the similar historical oppressions of each, are complex issues that Deaf and Disability Studies scholars seek to untangle (Burch \& Kafer, 2010). In sum, these foundational principles of Disability Studies (and Deaf and Disability Studies) outlined above assisted the authors in analyzing the participants' stories in the study.

\subsection{The context of Northern Ireland}

In studying access to the system of justice in Northern Ireland, the authors investigate the barriers that Symington and Carberry (2006) and Parks and Parks (2012) identify. They have estimated that more than 17,000 Deaf people in Northern Ireland experience when they try to access public services in Northern Ireland. According to Symington \& Carberry (2006:21),

Sign language is the preferred means of communication of 4500 of the 17,000 people in Northern Ireland who are severely or profoundly deaf and, of course, sign language is also used by a significant number of their families and friends. As well as helping to raise awareness of the particular requirements of Deaf people, this recognition [of BSL as an official national language] will also see the eleven Northern Ireland Government Departments joining forces to work proactively in partnership with representatives of the Deaf community to develop ideas for improving access to public services.

Underscoring the importance of Deaf people being able to access justice in Northern Ireland is the reality that when compared to hearing people, Deaf people do not enjoy the same economic well-being (Barnes \& Sheldon, 2010). In fact, those who are Deaf or hard of hearing experience the following challenges: (a) lower household income; (b) struggle to make ends meet; (c) inability to absorb unexpected expenses; and (d) higher rates of underemployment than their hearing counterparts (Kim, Byrne, \& Parish, 2018). These challenges highlight the barriers and discrimination Deaf people face in Northern Ireland, and again, emphasize the need for more equitable access to the system of justice. Such access, mandated by law, is needed to provide relief.

\subsection{Deaf access to justice around the world}

While it is certainly important to understand the local context of deafness as it relates to the system of justice in Northern Ireland, it is imperative that justice systems around the world are seen as similar as possible in structure, policy and practice, and stakeholders in these systems are able to inform one another of best practices related to accessing justice. The authors hope other researchers will be able to generalize findings from this project to different countries. The numbers presented in this paper are of particular global importance as roughly 466 million people, or about $5 \%$ of the world's population, experience some form of deafness (World Health Organization, 2018). 
In 2016, the United Nations ruled that Australian courts violated the rights of two Deaf people when called for jury service they were denied interpreting and real-time captioning support they required in order to participate in the court proceeding (United Nations, 2016). In a related case involving legal access, a UN Committee on the UNCRPD demanded a change in legislation and policy when the High Court of Australia ruled that a Deaf juror who required a sign language interpreter to access court proceedings would not be allowed to serve on a jury as the interpreter would be the $13^{\text {th }}$ person in the jury room (Spencer, San Roque, Napier, \& Hale, 2017).

Foregrounding these recent legal decisions in Australia is the work of Napier, Spencer, and Sabolcec (2007) utilizing quantitative and qualitative research to find that Australian Sign Language, Auslan, offered highly accurate interpretations of court proceedings and produced no significant difference in comprehension between Deaf and hearing court participants. The researchers concluded, "With trained and skilled interpreters, Deaf people could effectively access court proceedings via sign language interpreters, and perform their function as jurors" (Napier et al., 2007:viii).

In order for Deaf people to be better supported within the justice system, Napier and McEwin (2015:23) claim that sign language users around the world must be seen as members of a "linguistic and cultural minority" and should have access to interpreters when navigating the system of justice. Batterbury (2012) argues that if countries do not adopt strong disability policies that support the development of an official sign language, there can be no language justice for Deaf people. Based on their research in Wales, England, the United States, and Australia Eades \& Pavlenko, 2017 created a set of guidelines for language access for Deaf people to help police officers, lawyers, judges and justice administrators provide effective communication access. In the United States, according to Miller (2001:328),

Historically, the provision of sign language interpreters to Deaf suspects, defendants, and offenders has been problematic in the criminal justice system where inconsistency in the provision of interpreter services results largely from the ignorance of criminal justice professionals regarding Deaf people's communication needs and accommodation options.

Mor (2017) highlights that this historically unequal access to justice around the world limits Deaf people's ability to exercise their fundamental rights, including the right to petition the government for redress of a grievance. The derogation of access to justice leads to more Deaf people being incarcerated at a rate of more than 12 times higher than their hearing counterparts in high-security prisons (Young, Monteiro, \& Ridgeway, 2000). Kelly (2017:8) found that when Deaf people are imprisoned in the UK, "the pains and deprivations associated with imprisonment went way beyond those of other prisoners." These findings underscore the need for Deaf prisoners to receive specialized support while incarcerated (Bramley, 2007; Lemon, 2006). Put simply, proactive measures like the development and implementation of Deaf awareness courses for law enforcement and court personnel are needed so Deaf people have more equitable access to justice from the outset (Race \& Hogue, 2017).

\subsection{Research questions}

Recognizing the barriers related to Deaf people accessing justice in Northern Ireland described above, the authors designed the 2016 project to gather insight from Deaf people about their experiences accessing the justice system (Elder \& Schwartz, 2018). That initial project was guided by three key research questions:

1. How would education in the Deaf and legal communities about the DDA (1995) and Article 13 of the UNCRPD (2006) influence how Deaf people seek and/or gain access to the system of justice in Northern Ireland?

2. In what ways could systems and processes related to accessing justice, whether through solicitors, judges, the nonprofit sector, or NGOs, be devised to ensure Northern Ireland's effective compliance under the DDA and Article 13 of the UNCRPD?

3. How will collaboration between the stakeholders shape the degree to which Northern Ireland complies with the DDA and Article 13 of the UNCRPD? 
During the 2017 iteration of the project, the authors gathered additional data that could be used to guide education of the key stakeholders (e.g., Deaf people, court personnel, including solicitors and barristers, the police, and other instruments of state power) on the provision of effective communication access for Deaf people (Schwartz \& Elder, 2018). The 2017 iteration of the project was guided by the following research questions:

1. How do Deaf people interpret the concept of 'reasonable adjustment'?

2. How do Deaf people view their place and status in the system of justice?

3. What recommendations do Deaf people propose for the implementation of effective communication access in Northern Ireland's system of justice?

The research questions guiding the 2018-2020 iteration of the project ${ }^{2}$, at the time of writing, were currently being developed and approved by a group of Deaf advocates recruited from the Deaf community in Northern Ireland called the Deaf Advisory Group (DAG). The questions suggested by the DAG for project interviews with stakeholders in the system of justice (i.e., judges, barristers, solicitors, police officers, and prison officials) included the following:

1. Do people working in the system of justice know sign language, and if so, at what level of proficiency?

2. Do they know what BSL/ISL is?

3. Are they aware of the difference between BSL and ISL?

4. Would they be willing to learn sign language?

5. Would they be willing to pay for sign language training for stakeholders? If not, who would pay for it?

\section{Methods}

\subsection{Positionality}

At the center of this international CBPR-informed project is the authors' positionality, which influences and shapes their perceptions of the world. While the authors are not from Northern Ireland and cannot speak for Deaf people in the region, both have extensive experience conducting international, multilingual qualitative research with expertise in education and law, respectively. The authors consider themselves allies of the Deaf community and feel it is their responsibility to utilize the power that comes from their privileged academic positions in order to amplify the narratives of Deaf people attempting to gain greater access to the justice system in Northern Ireland. Both authors also strongly believe that their research practices need to actively deconstruct ableist structures that serve to marginalize disabled people. As it pertains to this work, the authors and participants are deeply committed to rejecting notions of audism and other forms of oppression that the participants and other members of the Deaf community have experienced.

Elder's positionality is inherently tied to how deafness and disability are constructed in the United States. He believes in the importance of allyship in international collaboration so that both researchers and participants have informed partners outside of their communities (Kincheloe \& Steinberg, 2008). Allyship entails "an active, consistent, and arduous practice of unlearning and re-evaluating, in which a person in a position of privilege and power seeks to operate in solidarity with a marginalized group" (The Anti-Oppression Network, 2015:1). Such a practice constitutes "a lifelong process of building relationships based on trust, consistency, and accountability with marginalized individuals and/or groups of people." (The Anti-Oppression Network, 2015:1). Elder is aware of the privilege and power he enjoys as a nondisabled, white, educated male, all the while trying to leverage his position in disability rights advocacy to support his allies who may not have those same privileges.Elder is conversant in

\footnotetext{
2 This iteration of the project was funded by the UK's Big Lottery and Disability Research on Independent Living \& Learning (DRILL) Programme.
} 
ASL and sees his research in Northern Ireland as a way to counter the negative social perception of deafness and disability.

Schwartz's positionality is constructed through his experience of being deaf since birth. He strongly believes, like Elder, in the importance of allyship, especially as it pertains to his disability rights work. As an educated white male, Schwartz is aware of his privileged position. Born profoundly deaf, he mastered the code of English, learning to read and write English with native fluency. Later in life, he acquired fluency in ASL and BSL. As a Deaf person, Schwartz brings to the table lived experience with communication barriers that has conditioned his thinking about living with deafness. His lived experiences with communication barriers helped gain access to the Deaf community in Northern Ireland, and he engages with his Northern Irish colleagues as an active way to push back against ableist notions of deafness and disability. For the authors, ableism is "a set of beliefs or practices that devalue and discriminate against people with physical, intellectual, or psychiatric disabilities and often rests on the assumption that disabled people need to be 'fixed' in one form or the other" (Smith, 2018:1). This understanding of ableism underwrites the two authors' position in the research.

\subsection{Community-Based Participatory Research (CBPR)}

To compliment and connect to the theoretical framework, the authors' research methods were also informed by CBPR to the extent possible given time and grant funding constraints. While there are myriad approaches to participatory research, the authors chose CBPR to address the complex multilingual realities of this project. A CBPR approach to research engages participants, who are subjects situated in the community, but not necessarily as equal partners in all phases of the project (i.e., analysis and publication) (Minkler \& Wallerstein, 2003). Researchers and participants collaborate to formulate research ideas, questions, and help guide research directions (Greenwood \& Levin, 1998; Wulfhorst, Eisenhauer, Gripne, \& Ward, 2008). In CBPR projects, researchers emphasize community and participant collaboration in order to develop and maintain collaborative practices where the main objective is the creation of actions that provide immediate and clear benefits to the target community (Israel, Schulz, Parker, \& Becker, 1998; Stanton, 2014). Like other forms of action research, the CBPR process is action-oriented, generating a sequence of outcomes with the aim of achieving the desired goal of social justice, and the focus of research shifts as the needs of the community change (Beh, Bruyere, \& Lolosoli, 2013; Somekh, 2006).

With each cycle of research in 2016 and 2017, and the 2018-2020 iteration, all research outcomes were and are directed by the Deaf population attempting to increase their access to the justice system in Northern Ireland (Elder \& Schwartz, 2018; Schwartz \& Elder, 2018). This means that participants were given regular opportunities to provide feedback on the emerging findings of each iteration of the project in the form of member checks (Creswell \& Miller, 2000; Lincoln \& Guba, 1985). Depending on the iteration of the project, at times the authors were in Northern Ireland and could ask participants for feedback directly with an interpreter present, while at other times they solicited feedback through Deaf colleagues at the British Deaf Association and Queen's University, Belfast. While time constraints limited the input of the Deaf community in Northern Ireland in the research design and the questions, the authors strove to keep the Deaf community up to date with their work.

\subsection{Timeline}

At the time of writing, the authors just completed the third iteration of this project. The project originated in 2015 when Schwartz was conducting research on Deaf access to the healthcare system for his Fulbright project for eight months (Schwartz, 2019). During the healthcare interviews, participants consistently reported they did not have access to multiple public systems, including the justice system. This led to the authors developing a justice-related project in Northern Ireland. The authors received two small-scale grants from Schwartz's university and shortly thereafter received institutional review board (IRB) approval. These grants allowed for the first iteration of the project to begin in June 2016 for two weeks, and continue for the second iteration in August 2017 also for two weeks. These small-scale grants led to the authors being awarded a grant from the Big Lottery through the UK government that began a third iteration of the project in June 2018 and lasted until 2020. During that two-year period, 
the authors took five one-week trips to Northern Ireland. At the time of writing, the authors had just completed the data collection phase of the third iteration during which they conducted interviews and focus groups with other stakeholders in the system of justice including judges, barristers, solicitors, police officers, and prison officials.

\subsection{Data collection}

In 2016 and 2017, the authors collected data in the form of 17 audio-recorded semi-structured interviews, eight in 2016, and nine in 2017. For more information on the themes explored through the interviews, see the Interview Guide in Appendix A. Interviews of the Deaf subjects resulted in spoken English interpretation which was then transcribed line-by-line. The interpreters retained for this task were recommended by members of the Deaf community based on their intimacy and closeness with the community. By relying on interpreters who were known, respected and trusted in the Deaf community of Northern Ireland, the authors avoided the colonization of spoken English over sign language. The authors decided not to videotape the interviews because it would have resulted in redundancy of labor; videotaping would have required a BSL or ISL interpreter to watch the tape and voice the Deaf person's signs. A more efficient use of time would be to have the interpreter voice the Deaf person's signs in real time. Following each project event or meeting, the authors wrote memos to debrief and develop shared understandings of interviews with participants. As noted above, the authors regularly shared these emerging findings with participants in various ways. In 2016, the authors conducted eight individual interviews (i.e., one participant, two researchers, one interpreter) that lasted roughly 30 to 40 minutes each. In 2017, the authors conducted nine individual interviews that were of the same length. The interviews in both years were conducted at various locations depending on proximity to the participants' residences and places of employment.

\subsection{Data analysis}

As noted earlier, in the spirit of transparency, the authors would like to make clear that due to time and financial limitations inherent in small-scale grants, they could not involve participants in all aspects of the project, which included the data analysis portion of the project. While the authors asked participants to verify the accuracy of the quotes, and conducted member checks at the end of each iteration of research (Creswell \& Miller, 2000; Lincoln \& Guba, 1985), they recognize this modified approach to CBPR as a limitation and it explains why they say "CBPR-informed research practices" throughout this article.

In 2016 and 2017, the authors used traditional methods of qualitative research like a constant comparison method and constructivist grounded theory approach to conduct their data analysis (Charmaz \& Mitchell, 2001), the authors engineered an approach that allowed for a simultaneous evaluation and collection of data and findings (Charmaz, 2005). The authors used Bogdan and Biklen's (2007) coding procedures to analyze the data. The authors coded data in three phases: open coding, axial coding, and selective coding. This process helped identify three salient themes for the 2016 and 2017 iterations of the project, which we expand upon in the following paragraph (Creswell, 2013). The authors coanalyzed data systematically to maintain inter-coder reliability (Patton, 2002). The authors organized and maintained the data with Dedoose software (Lieber \& Weisner, 2015), and through this analysis were able to focus on data that informed their understanding of the barriers to Deaf people accessing justice in Northern Ireland.

While open coding the data, the authors read transcribed interviews line-by-line and collectively came up with codes. Some examples of codes include: "Experience with Jury Service," "Importance of Interpreters," and "Preferred Methods of Communication." To further understand the data, the authors used features in Dedoose (Lieber \& Weisner, 2015) such as the "Packed Code Cloud" and "Code Co-Occurrence" to identify the three most salient themes that emerged from the open coding process. In 2016, those themes were: "Barriers to Access," "The Contested Meaning of 'Reasonable Adjustment'," and "Deaf Cultural Awareness" (Schwartz \& Elder, 2018). In 2017, the three most salient themes included: "Fiscal and Institutional Barriers to Accessing Justice," "The Work that Deaf People Do to Access Justice," and "The Need to Educate Solicitors About Access" (Elder \& Schwartz, 2018). 
Upon further analyzing the themes, the authors began the selective coding process during which they identified the participant quotes that most forcefully illustrated each theme. It is important to note that during the coding process, a large number of important codes and themes arose from the interviews. Many of the codes intersected with and were related to other codes and themes. For example, some participants described their experiences facing discrimination at work and the subsequent barriers when attempting to file a case in the legal system. Finding the most important aspects of these impactful experiences during the coding process was a challenge. This reality required the authors to use their best judgment to identify quotes that best captured each theme while still understanding the intersectional relation to other themes. It is worth noting that while the participants were not actively a part of the analysis process outlined above, the periodic member checks helped the authors pay attention to specific aspects of interviews participants felt were important to them and their personal experiences within the system of justice. In order to do in-depth member checks, as mentioned above, the authors relied on the DAG to affirm emerging findings and approve the dissemination of any analysis in conference presentations and subsequent publications (Byrne, Elder, \& Schwartz, 2021).

\subsection{Recruitment of participants}

In 2016, as a result of his personal relationships with many in the local Deaf community, Schwartz enlisted eight participants through email and SMS. The authors selected participants based on their lived experiences as Deaf people living under the system of justice in Northern Ireland. The authors interviewed eight Deaf and hard-of-hearing participants who were 18 years of age or older, and who had one or more interactions within the justice system (e.g., interacting with solicitors, barristers, judges or other members of the civil side of the system of justice) (Schwartz \& Elder, 2018).

In 2017, the authors amended their IRB from their respective institutions to include more participants. Schwartz recruited nine adult participants through email and SMS, and the authors chose participants based on their lived experiences as Deaf people living under the system of justice in Northern Ireland (Elder \& Schwartz, 2018). For more detail on participants, see Table 1.

During each iteration of research, providing an interpreter fluent in BSL and ISL was central to the project since spoken English was not the preferred language of most participants. The authors encouraged the participants to communicate in their preferred language. While the interpreter retained by the authors was fluent in both BSL and ISL, based on the communicative preferences of participants, the authors conducted each interview in BSL. While Schwartz signed BSL to participants, Elder recorded the interviews on an iPhone and took notes. Elder took notes and recorded interviews as a way to create a permanent record that he could access should Schwartz or any of the participants want clarification or reminders about what was relayed in the interviews. While none of the participants requested clarification, or needed reminders about what was said, should that need have arisen, the authors would have provided the interview transcripts to the participant and offered to engage a BSL or ISL interpreter to ensure access to the transcriptions that were typed in English.

The team of interpreters retained to communicate effectively with the Deaf subjects were not "coresearchers" trained to understand the authors' methodological approaches. Aside from an occasional check with the interpreter to make sure communication was effective, the interpreters did not engage in any reflexivity on their involvement. Most of the interpreters retained for the interviews were CODA (children of Deaf adults) who had been recommended by the Deaf subjects because of their closeness to, and familiarity with, the Deaf community.

It is also important to note the impact of Schwartz's deafness on the data collection aspect of the project. Since Schwartz could not hear the interpreter voicing his signs during the interviews, he read the transcripts afterward. He noted that while most of the interpreter's voicing was accurate, there were a few questions voiced by the interpreter that Schwartz did not recognize as a faithful representation of the questions he signed. Most of the questions voiced by the interpreter were close to what Schwartz signed and yielded an appropriate response from the participants. However, in the interest of transparency, it is important to mention the challenge of not being able to hear the interpreter's voice during the interviews. It is also worth noting that while Elder is conversant in ASL, 
Table 1

Participant characteristics.

\begin{tabular}{|c|c|c|c|c|c|}
\hline Name & Age & Gender & $\begin{array}{l}\text { Communication } \\
\text { Preference }\end{array}$ & Experience with the Justice System & $\begin{array}{l}\text { Year of } \\
\text { Interview }\end{array}$ \\
\hline 1. Maeve & 58 & $\mathrm{~F}$ & Spoken English and BSL & Divorce, jury service & 2016 \\
\hline 2. Alana & 43 & $\mathrm{~F}$ & $\begin{array}{l}\text { Spoken English, some } \\
\text { BSL }\end{array}$ & Mortgage advice, court witness & 2016 \\
\hline 3. Fiona & 40 & $\mathrm{~F}$ & Spoken English and BSL & Legal advocate for Deaf people & 2016 \\
\hline 4. Conor & 50 & M & BSL and ISL & $\begin{array}{l}\text { Jury summons, mortgage advice, } \\
\text { writing a will, employment } \\
\text { discrimination }\end{array}$ & 2016 \\
\hline 5. Aiden & 73 & M & BSL & $\begin{array}{l}\text { Mistaken identity regarding a crime, } \\
\text { mortgage advice, set up a trust, } \\
\text { employment discrimination }\end{array}$ & 2016 \\
\hline 6. Peadar & 41 & M & BSL & $\begin{array}{l}\text { Employment discrimination, car } \\
\text { accident, worked in court services, jury } \\
\text { summons }\end{array}$ & 2016 \\
\hline 7. Sean & 32 & M & BSL & Parents are solicitors, car accident & 2016 \\
\hline 8. Kiernan & 50 & M & BSL & Traffic violations, job discrimination & 2016 \\
\hline 9. Aiden & 31 & M & BSL & $\begin{array}{l}\text { Purchasing a house, interacting with } \\
\text { police following an assault on his } \\
\text { person }\end{array}$ & 2017 \\
\hline 10. Aoife & 68 & $\mathrm{~F}$ & BSL & $\begin{array}{l}\text { Purchasing a house, attempted assault } \\
\text { on her person }\end{array}$ & 2017 \\
\hline 11. Bartley & 42 & M & BSL & $\begin{array}{l}\text { Wife's car accident, wife's profession as } \\
\text { a legal advocate for Deaf people }\end{array}$ & 2017 \\
\hline 12. Ciaran & 40 & M & BSL & $\begin{array}{l}\text { Purchasing a house, witness to a car } \\
\text { accident }\end{array}$ & 2017 \\
\hline 13. James & 66 & M & BSL & $\begin{array}{l}\text { Purchasing a house, Equality } \\
\text { Commission }\end{array}$ & 2017 \\
\hline 14. Liam & 78 & M & BSL & Purchasing a house, traffic violations & 2017 \\
\hline 15. Maire & 74 & $\mathrm{~F}$ & BSL & Equality Commission, testified in court & 2017 \\
\hline 16. Padraig & 70 & M & Spoken English and BSL & $\begin{array}{l}\text { Helped set up interpreting services in } \\
\text { Northern Ireland }\end{array}$ & 2017 \\
\hline 17. Ronan & 39 & M & BSL & Purchasing a house & 2017 \\
\hline
\end{tabular}

he is not conversant or fluent in BSL or ISL. As a result, Elder relied on the interpreter to voice all of the participant responses.

\subsection{Participant responses}

While the focus of this paper is on research methods, the authors feel it is important to ground this work in direct quotes from Deaf participants that effectively relay their often-oppressive experiences in attempting to access the system of justice in Northern Ireland. The 17 qualitative interviews the authors conducted during the first two iterations of this project yielded substantial amounts of data. These stories brought to light the pressing realities Deaf people face in accessing the system of justice in a country with available resources. The data presented here supports the main objective of this project-to better understand the barriers that Deaf people face when attempting to access the system of justice in Northern Ireland and to present our methods in a manner that is clear to others who wish to engage in similar work in other locations. The authors present these excerpts as one way to highlight the results of their methodological choices, as well as to better ground participants' experiences through CBPR-informed research methods.

\subsection{Preferred method of communication}

In this first excerpt from the 2016 iteration of the project, Sean explains his preferred method of communication when it comes to taking in new information: 
SCHWARTZ: When it comes to information, would you prefer that it's in written word or would you prefer that it was recorded and had captions?

SEAN: I would prefer to watch something that was recorded and presented in sign language. You know that would be my main preference if I could get the information directly in sign language I would prefer that. Obviously, I can read up a lot too but with sign language being my first language I would prefer that I got information directly in that. Written English is something that I would probably need to spend a bit more time getting my head around whereas in sign language if it's presented in sign language I'm going to get it more directly.

This excerpt represents the authors' conscious methodological attempt to treat Deaf participants as a "linguistic and cultural minority" within the research context (Napier \& McEwin, 2015:23). This quote reflects why the authors put such a methodological emphasis on providing participants with their preferred communication choice throughout all iterations of the project. Sean's comment about sign language reflects an almost universal desire among Deaf people around the world for a language that is easily accessible to them, and the authors strongly feel this should be reflected in the research design when conducting research within Deaf communities. A denial of access is a denial of justice not just in Northern Ireland, but for people around the world. Such denial is a violation of the UNCRPD (2006) and is not in alignment with the "reasonable adjustment" provision of the DDA (1995). Sean's communicative preference of signed communication is similarly expressed by Conor in this excerpt from 2016:

SCHWARTZ: Conor, do you know about speech-to-text where a spoken word is transcribed live? Would you like to use something like that or would you go for a sign language interpreter? CONOR: I would find watching everything that's spoken just coming up as text quite tiring. I would prefer things to be interpreted. I would also be fearful that there may be some words I might not have come across before. And also I would feel a bit unsure about really speaking up for myself if I was just working off the written transcription of what was said. I know an interpreter will follow what I say and it will be accurate, and I feel more competent about responding... SCHWARTZ: So, you're preferred mode of communication is...?

CONOR: I would use British Sign Language and Irish Sign Language.

SCHWARTZ: So, is your first language English or sign language?

CONOR: My first language is sign language and my second language is English.

Conor's response here underscores why the authors chose to provide participants with choices in terms of their preferred mode of communication within the project. This approach privileges participant narratives and preferences within Disability Studies- and Deaf and Disabilities Studies-centric research (Burch \& Kafer, 2010; Ferguson \& Nusbaum, 2012).

\subsection{The cost of accommodations}

In the following excerpt from 2017, Padraig describes his experiences collaborating with a local university's law department on Deaf access to justice:

PADRAIG: Every effort has been made to try and influence solicitors. As you know, we have been working with the law department at [a local university], and that has been ongoing for over 20 years providing training for solicitors' training at the university. And you'd like to think there's a better awareness but also know that if they are going to really represent their Deaf clients then funding has to be provided for an interpreter.

Here, Padraig discusses how despite collaborating for over two decades with a university to encourage solicitors who graduate from their program to be more accessible to the Deaf population (Symington \& Carberry, 2006), the discussion about who pays for the interpreting services is still up for debate, despite mandates outlined by the DDA (1995) and the UNCRPD (2006). If the system of justice still struggles with the concept of access when a university with this much experience and resources advocates for Deaf access to justice, imagine how much the research community around the world has to learn when attempting to engage the Deaf community in research to remove barriers to 
justice in countries with fewer resources than Northern Ireland. As it pertains to conducting research with Deaf communities, this quote underscores that it is non-negotiable that costs associated interpretation and communication preferences and access be considered and accounted for at the outset of any such research project.

\subsection{Advice to legal professionals}

In this next excerpt from 2017, the authors encourage readers to substitute the words "solicitors," "police officers," and "judges" with the word "researchers":

SCHWARTZ: If you had an opportunity to talk with solicitors, police officers, judges, what would you tell them? What would be the first thing you would tell them that is so important for them to be aware of?

BARTLEY: I would just let them know that we are equal citizens, we have rights. They need to know that and we need to be treated the same as anyone else. And I would ask them how are you going to make sure we are treated equally. How will they make sure that every Deaf person no matter whatever service they come in contact with the police service, the justice service, solicitors, how are they going to make sure the appropriate access is in place because they need to be thinking about that. What can they do to change their services for the better so that a Deaf person has the same access and the same rights as any other citizen?

Here, Bartley calls for a human rights approach to accessing justice as outlined by Article 13 of the UNCRPD (2006). Bartley is talking about respect for Deaf people in the system of justice, and agreeing with Bartley, the authors argue that a human rights approach should be undertaken when it comes to international and multilingual research, especially within Deaf communities. In particular, access to communication should be framed as a universal human right (Universal Declaration of Human Rights, 1948), especially as it pertains to accessing justice. Again, access denied is justice denied, and this transcends political borders, and research methods should model this access. In order to move in an action-oriented direction when it comes to research that liberates Deaf people, it is important to keep James' words in mind that he expressed in 2017:

JAMES: I would say we are Deaf people, we are just like you, we are humans like you. But what you have and want, what your haves and wants are the same as our haves and wants, exactly the same. I would want to make it clear and I do this all the time. When I'm talking to people, I explain we have wants and dreams just like you. We're fighting for equality.

James reminds us that the engaging historically marginalized populations in research requires more than a basic commitment to adhere to ethical research practices. The authors argue that engaging in CBPR-informed research practices requires an honest acknowledgment of what is at stake on behalf of participants and researchers. From what the authors have learned from their Northern Irish colleagues, more is at stake than simply adhering to an IRB approved by the researcher's university, publishing a paper, and moving on to the next project. The authors argue that researchers engaging in CBPR-informed research must take action to dismantle oppressive systems, which they hope they've made clear in this paper. A systemic denial of access to justice has a material impact on those being marginalized or otherwise barred by an inaccessible system of justice and requires a deeper commitment on all parties involved in such research to take action to address these inequalities (Grech, 2011). Not only do these actions need to be taken, but like in this project, the authors are determined to lend their work to the struggle by and for Deaf people in order to further dismantle the barriers to justice not only in Northern Ireland and beyond. Such an approach reflects the disability rights mantra, "Nothing about us without us," used by disability advocates around the world (Charlton, 1998:3).

\section{Limitations}

One limitation of this ongoing project is that the authors did not involve participants in the coding and analysis of data as outlined by Patton (2002). Though the authors did conduct member checks 
(Creswell \& Miller, 2000; Lincoln \& Guba, 1985), at the end of each iteration of research, due to the brevity of the in-country research activities, the authors could not effectively engage participants in the data coding and analysis process. Many realities contributed to this limitation, including limited time for participant training on qualitative methodologies, and limited time to discuss the results in a meaningful way. While the authors did not collectively publish findings during the 2016 and 2017 iterations of the project, with funding from the UK government for the 2018-2020 iteration of the project, the authors and the research team have organized a Deaf Advisory Group, which will help remediate this limitation in future project activities.

For future work, the authors are mindful of the need to adopt an inclusive research methodological approach that contains "both a capacity developmental component and intensive training in disability policy knowledges and practices" (Samararatne, Soldatic, \& Perera, 2018:12). This methodological approach rests on a number of guiding principles central to the research process: the research questions must be accessible to the Deaf community involved with this project; Deaf people are to be regarded as subjects with expert knowledge; Deaf people are active in the entire research from formulating questions to the gathering of data to analysis and dissemination of the results; and, the material must be accessible via captioning and sign language (Samararatne et al., 2018).

Another limitation is that the authors live and work in the United States. However, it is worth noting that Schwartz has visited Northern Ireland approximately 30 times in the last 36 years, and has extensive experience conducting research in the region with the Deaf community. At the time of writing, Elder has worked in Northern Ireland on five occasions, but he recognizes that these experiences do not position him as an authority on deafness in the region. Along these same lines, another limitation is that Elder is hearing and is conversant in ASL. He can sign as a result of having taught Deaf children in the past as a special educator. He also has many Deaf friends and colleagues. However, his ability to communicate in ASL does not translate into him being any sort of expert on ASL research or into any fluency in BSL. Elder relied completely on the BSL/ISL interpreters to give sign to his voice.

As mentioned above, an additional limitation is that Schwartz could not hear the interpreter voicing his signs during participant interviews. As a result, when analyzing transcripts, he realized that some of the questions he asked were interpreted in ways that shaped participant responses. One example is that the interpreter used the participant's name when Schwartz did not. Further, when reading interview transcriptions, Schwartz did not recognize some of the interpreter-voiced questions as an exact representation of how he framed and asked questions. For example, when Schwartz signed, "What is your preferred method of communication?" The interpreter voiced, "Do you prefer to use speech? BSL? ISL? In what way do you feel most comfortable communicating?" This does not mean the interpreter was not accurate or ineffective. The authors simply want to acknowledge this discrepancy in the spirit of transparency in research. A critical final limitation the authors recognize is the size of the study. At the time of writing the authors had interviewed 17 Deaf people in Northern Ireland and as a result of this ongoing project do not claim to speak for the entire Deaf community. Nor do they consider the 17 participants as a monolithic and monolingual representation of the entire Deaf community in the region.

\section{Discussion and conclusion}

When the authors began this project, they wanted to know how Deaf people thought about increasing access to the justice system for their community in Northern Ireland. The authors were aware of the methodological complexities of engaging in such research, especially considering the multilingual aspects of this work. Through the application of CBPR-informed research methodologies, the authors wanted to privilege the lived experiences that Deaf people shared with respect to the barriers they experienced when attempting to access justice in Northern Ireland. The research that exists on this topic highlights the myriad barriers Deaf people encounter within the justice system (for specific examples see: Batterbury, 2012; Bramley, 2007; Eades \& Pavlenko, 2017; Kelly, 2017; Lemon, 2006; Miller, 2001; Mor, 2017; Napier \& McEwin, 2015; Napier, Spencer, \& Sabolcec, 2007; Race \& Hogue, 2018; Spencer, San Roque, Hale, \& Napier, 2017; Young, Monteiro, \& Ridgeway, 2000), but does not discuss how to engage Deaf people in the research in order to collectively remove such barriers. This project goes beyond assessing Deaf barriers to justice. Rather than simply asking, "What 
are the barriers Deaf people face?," the authors ask, "How can we engage the Deaf community to remove these barriers in Northern Ireland and beyond?" and adjust our methods to engage the widest range of Deaf people (e.g., Samararatne et al., 2018:11).

One of the more significant implications of this project is the potential for replication in countries. While the authors understand that the scope of this work is small, and methodologies were applied only in Northern Ireland, they hope that partnerships between researchers and members of Deaf communities in other counties will be formed and the methods described in this article can be modified and replicated to fit other country contexts. The authors believe the methodologies used in this project have the potential to promote the participation of Deaf people to actively remove barriers to justice that they face. Engaging in such research practices with Deaf people has the potential to amplify the stories Deaf people that have historically been ignored. These approaches to research have the potential to increase the presence of these narratives in research. Legal professionals and the research community have a lot to learn by acknowledging Deaf people as strong sources of resistance to oppressive structures that have historically been inaccessible, like the justice system.

In this methodology paper, the authors have provided one example of what multilingual qualitative research methods can look like when informed by CBPR methodology. Through two cycles of qualitative interviews and a third iteration of the project currently underway with the Deaf community in Northern Ireland, the authors have learned a great deal about the barriers Deaf people face when attempting to access justice in Northern Ireland. The authors collected and analyzed data that placed lived experience with deafness at the center of the research. Participants shared the multiple ways in which they navigated a system that perpetuates systemic disability oppression as it related to accessing justice in Northern Ireland (e.g., relying on a family member to interpret when interacting with police; writing notes back and forth with a solicitor instead of having access to an interpreter). By sharing their methods, the authors hope that such approaches to research can be used by scholars and activists in other countries to break down barriers to the system of justice for Deaf people.

The main objective of using these methodologies was to better understand the barriers to the justice system that Deaf people experience. At the time of writing, the UK government-funded 20182020 iteration of the project was underway. In this iteration of the project, the authors, along with research partners at a university in Northern Ireland, a Deaf advocacy group, and members of the Deaf community who constitute the DAG will deliver six training sessions to members of the Deaf community, which can include organizing tours of various sectors within the system of justice, and provide presentations on how to effectively access the justice system. The sectors of the justice system that are under consideration include but are not limited to solicitors, barristers, the Police Service of Northern Ireland, the prison service, the judiciary, and the tribunals service. This will lead to the development and piloting of a training program for legal professionals and eventually lead to the creation of training materials, the delivery of training sessions, the development of online resources in both BSL and ISL for Deaf people on how the justice sectors operates, and the development of online resources for legal professionals to help them learn how to effectively accommodate Deaf people who need to access the system.

\section{Funding}

This project was made possiible through the Syracuse University Small Scale Funds Award and the Syracuse University Burstyn Endowed Fund for Collaborative Research Competition.

\section{Disclosure of interest}

The authors declare that they have no competing interest.

\section{Acknowledgments}

We would like to thank our Deaf colleagues in Northern Ireland without whom this work would not be possible. We owe a debt of gratitude to Dr. Bronagh Byrne of Queen's University, Belfast, and 
to our partners at the British Deaf Association, Holly Lane, Majella McAteer, and Julie Loughran. This work exists because of your deep commitments to social justice and deaf rights.

\section{Appendix A. Interview Guide 2016 and 2017: Deaf and Hard of Hearing Persons}

Our interviews will be open-ended and improvisational, so the following outlines topics to cover, rather than specifying particular questions. Each interview will explore the information introduced by the participant, covering the topics included in the guide only to the extent that they seem appropriate for each participant.

\section{Introduction}

- Born deaf or hearing? Identify as Deaf or Hard of Hearing?

- What is your preferred mode of communication?

- What's your preferred mode in the solicitor's office? In court?

\section{Goals}

- What are your goals when you seek and receive legal assistance?

- What do you think your provider's goals are?

- What is your view of the solicitor's financial, educational, social status?

\section{Communication}

- Do you use an interpreter in the solicitor's office? In court? How do you get one?

- Describe what it is like working with an interpreter with the solicitor? In court?

- Do you have email capability with your solicitor?

- How can you tell when you're communicating effectively with your solicitor?

- What kinds of problems do you encounter?

- Thinking about these kinds of encounters, tell us more about what works well, and then about the kinds of situations where you haven't felt so successful.

- Are you familiar with VRI technology, and have you used it? Your views on this technology?

- Visual aids in the solicitor's office - available to you?

\section{Navigating the Judicial Setting}

- Tell us how you find your solicitor? (phone book, word of mouth?)

- Describe your relationship with your solicitor

- Do you do a background check on your solicitor?

- Outline the steps you take from when you arrive to when you leave

- Describe the lighting and the seating

- Do you use the Internet for information about your legal rights?

- Do you ever ask for a second opinion?

\section{Legal Issues}

- We're interested in the Disability Discrimination Act and the UN Convention on the Rights of Persons with Disabilities. Both are in effect in the UK. Are you aware of these laws? Specify?

- To the extent you know these laws, are they working for you? How do you think it has affected access to the system of justice for Deaf people?

- How do you think the law might be improved?

- Informed consent

- Competency 


\section{Concluding Questions and Remarks}

- If speaking to a group of solicitors and judges, what would you say?

- Is there anything else you'd like to tell us about working with solicitors?

- Do you identify yourself as having any other disability?

- Would you be willing to meet with us again if we have any follow-up questions?

- Thank you for taking the time to meet with

\section{References}

Baglieri, S., Valle, J. W., Connor, D. J., \& Gallagher, D. J. (2011). Disability studies in education: The need for a plurality of perspectives on disability. Remedial and Special Education, 32(4), 267-278. https://doi.org/10.1177/0741932510362200

Barnes, C., \& Sheldon, A. (2010). Disability, politics and poverty in a majority world context. Disability \& Society, 25(7), 771-782. https://doi.org/10.1080/09687599.2010.520889

Batterbury, S. C. (2012). Language justice for sign language peoples: The UN Convention on the Rights of Persons with Disabilities. Language Policy, 11(3), 253-272. https://doi.org/10.1007/s10993-012-9245-8

Bauman, H., \& Murray, J. (2009). Reframing: From hearing loss to Deaf gain. Deaf Studies Digital Journal, 1(2009), 1-10.

Beh, A., Bruyere, B. L., \& Lolosoli, S. (2013). Legitimizing local perspectives in conservation through communitybased research: A photovoice study in Samburu, Kenya. Society \& Natural Resources, 26(12), $1390-1406$. https://doi.org/10.1080/08941920.2013.805858

Bogdan, R., \& Biklen, S. K. (2007). . Qualitative Research for Education: An Introduction to Theories and Methods (Vol. 5) Boston, MA: Pearson.

Bramley, S. (2007). Working with deaf people who have committed sexual offences against children: The need for an increased awareness. Journal of sexual aggression, 13(1,), 59-69. https://doi.org/10.1080/13552600701365530

Burch, S., \& Kafer, A. (2010). Deaf and Disability Studies: Interdisciplinary perspectives. Washington: Gallaudet University Press.

Charlton, J. I. (1998). Nothing about us without us: Disability oppression and empowerment. Berkeley, CA: University of California Press.

Charmaz, K. (2005). Grounded theory in the 21st century: Applications for advancing social justice studies. In N. K. Denzin, \& Y. S. Lincoln (Eds.), The Sage handbook of qualitative research. Thousand Oaks, CA: Sage Publications (pp. 507-535).

Charmaz, K., \& Mitchell, R. G. (2001). Grounded theory in ethnography. In P. Atkinson, A. Coffey, D. Delamont, J. Lofland, \& L. H. Lofland (Eds.), Handbook of ethnography. London: Sage Publications (pp. 160-174).

Creswell, J. (2013). Qualitative inquiry and research design: Choosing among five approaches (3rd ed.). Thousand Oaks, CA: Sage Publications, Inc.

Creswell, J. W., \& Miller, D. L. (2000). Determining validity in qualitative inquiry. Theory into practice, 39(3), 124-130. https://doi.org/10.1207/s15430421tip3903_2

Disability Discrimination Act (DDA). (1995). Disability Discrimination Act 1995.. Retrieved from http://www.legislation.gov.uk/ukpga/1995/50/contents

Emery, S. D. (2006). Citizenship and the deaf community (Doctoral dissertation). Retrieved from EThOS (0000 000134474632 ).

Ferguson, P. M., \& Nusbaum, E. (2012). Disability studies: What is it and what difference does it make? Research and Practice for Persons with Severe Disabilities, 37(2), 70-80.

Grech, S. (2011). Recolonising debates or perpetuated coloniality? Decentering the spaces of disability, development and community in the global South. International Journal of Inclusive Education, 15(1), 87-100. https://doi.org/10.1080/13603116.2010.496198

Greenwood, D. J., \& Levin, M. (1998). Introduction to action research: Social research for social change. Sage: Thousand Oaks, CA.

Hehir, T. (2002). Eliminating ableism in education. Harvard Educational Review, 72(1), 1-33. https://doi.org/10.17763/haer.72.1.03866528702g2105

Hooks, B. (1989). Talking back: Thinking feminist, thinking black. Boston: South End Press.

Israel, B. A., Schulz, A. J., Parker, E. A., \& Becker, A. B. (1998). Review of community-based research: assessing partnership approaches to improve public health. Annual Review of Public Health, 19(1), $173-202$. https://doi.org/10.1146/annurev.publhealth.19.1.173

Kelly, L. (2017). Suffering in Silence: The unmet needs of d/Deaf prisoners. Prison Service Journal, (234), 3-15 (Retrieved from http://clok.uclan.ac.uk/20669/)

Kim, E. J., Byrne, B., \& Parish, S. L. (2018). Deaf people and economic well-being: findings from the Life Opportunities Survey. Disability E Society, 33(3), 374-391. https://doi.org/10.1080/09687599.2017.1420631

Kincheloe, J., \& Steinberg, S. (2008). Indigenous knowledges in education: Complexities, dangers, and profound benefits. In N. K. Denzin, Y. S. Lincoln, \& L. T. Smith (Eds.), Handbook of critical and indigenous methodologies. Thousand Oaks, CA: Sage (pp. $135-156)$.

Kusters, A., \& De Meulder, M. (2013). Understanding Deafhood: In search of its meanings. American Annals of the Deaf, 157(5), $428-438$.

Kusters, A., De Meulder, M., Friedner, M., \& Emery, S. (2015). On “diversity" and "inclusion": Exploring paradigms for achieving sign language peoples' rights (Position paper).. Retrieved from https://pure.mpg.de/rest/items/item_2125474/component/file_2125472/content

Ladd, P. (2003). Understanding deaf culture: in search of deafhood. In Understanding deaf culture (1st ed.). Multilingual Matters.

Ladd, P. (2005). Deafhood: A concept stressing possibilities, not deficits. Scandinavian Journal of Public Health, 33(66_suppl), $12-17$. 
Lemon, N. K. (2006). Access to Justice: Can Domestic Violence Courts Better Address the Need of Non-English Speaking Victims of Domestic Violence. Berkeley Journal of Gender, Law E Justice, 21, 38 (Retrieved from https://heinonline.org/HOL/LandingPage?handle=hein.journals/berkwolj21\&div=7\&id=\&page=)

Lieber, E., \& Weisner, T. (2015). Dedoose (Version 6.1.18) [Software].. Available from www.dedoose.com

Lincoln, Y. S., \& Guba, E. G. (1985). Naturalistic inquiry. Newbury Park, CA: Sage.

Linton, S. (2006). Reassigning meaning. In L. Davis (Ed.), The disability studies reader. New York, NY: Taylor \& Francis Group (pp. $161-172)$.

Linton, S. (2005). What is disability studies? PMLA, 120(2), 518-522 (Retrieved from http://www.jstor.org.ezproxy.rowan.edu/stable/25486177)

McCarthy, C. (1998). The uses of culture: Education and the limits of ethnic affiliation. New York: Routledge.

McDonnell, P. (2016). Disability, deafness and ideology in the late twentieth and early twenty first centuries. Educação E Realidade, 41(3), 777-788. https://doi.org/10.1590/2175-623661091

Mercer, G. (2002). Emancipatory disability research. In C. Barnes, M. Oliver, \& L. Barton (Eds.), Disability studies today. Maiden, MA: Blackwell (pp. 228-249)

Miller, K. R. (2001). Access to sign language interpreters in the criminal justice system. American annals of the Deaf, 146(4), 328-330. https://doi.org/10.1353/aad.2012.0188

Minkler, M., \& Wallerstein, N. (Eds.). (2003). Community-based participatory research for health. San Francisco, CA: Jossey-Bass.

Mor, S. (2017). With Access and Justice for All. Cardozo Law Review, 39, 611 (Retrieved from https://heinonline.org/HOL/LandingPage?handle=hein.journals/cdozo39\&div=21\&id=\&page=)

Napier, J., \& McEwin, A. (2015). Do Deaf people have the right to serve as jurors in Australia? Alternative L.J., 40(1), 23-27. https://doi.org/10.1177/1037969X1504000106

Napier, J., Spencer, D., \& Sabolcec, J. (2007). Guilty or not guilty?: An investigation of Deaf jurors' access to court proceedings via sign language interpreting. NSWLRC Research Report No, 14, 72-122.

Padden, C. A., \& Humphries, T. (1990). Deaf in America. Cambridge, MA: Harvard University Press.

Padden, C. A., \& Humphries, T. (2009). Inside Deaf culture. Cambridge, MA: Harvard University Press.

Parks, E., \& Parks, J. (2012). A survey report of the Deaf people in Northern Ireland. SIL International. Retrieved from http://www-01.sil.org/silesr/2012/silesr 2012-001.pdf

Patton, M. Q. (2002). Qualitative education and research methods (3rd ed.). Thousand Oaks, CA: Sage Publications.

Race, L., \& Hogue, T. E. (2018). 'You have the right to remain silent' Current provisions for D/deaf people within regional police forces in England and Wales. The Police Journal, 91(1), 64-88. https://doi.org/10.1177/0032258X16689689

Samararatne, D., Soldatic, K., \& Perera, B. (2018). A study of war-affected women with disabilities in Sri Lanka. Pre-consultation Report. Penrith, Australia: Western Sydney University, Institute for Culture and Society.

Shapiro, A. (1999). Everybody belongs: Changing negative attitudes toward classmates with disabilities. New York, NY: Routledge Falmer.

Smith, L. (2018). \#Ableism. Center for Disability Rights.. Retrieved from http://cdrnys.org/blog/uncategorized/ableism/

Solvang, P. K., \& Haualand, H. (2014). Accessibility and diversity: Deaf space in action. Scandinavian Journal of Disability Research, 16(1), 1-13.

Somekh, B. (2006). Action research: A methodology for change and development. In P. Sikes (Ed.), Doing qualitative research in educational settings. New York, NY: Open University Press.

Spencer, D., San Roque, M., Hale, S., \& Napier, J. (2017). The high court considers participation of deaf people in jury duty. Law Society Journal, (33), 80-81 [https://researchportal.hw.ac.uk/en/publications/the-high-court-considers-participationof-deaf-people-in-jury-dut].

Stanton, C. R. (2014). Crossing methodological borders decolonizing community-based participatory research. Qualitative Inquiry, 20(5), 573-583. https://doi.org/10.1177/1077800413505541

Symington, B., \& Carberry, J. (2006). British and Irish Sign Languages: The long road to recognition. Belfast, Northern Ireland: The Linen Hall Library.

The Anti-Oppression Network. (2015). Allyship.. Retrieved from https://theantioppressionnetwork.com/allyship/

Universal Declaration of Human Rights. (1948). Retrieved from http://www.un.org/en/universal-declaration-human-rights/.

United Nations. (2016). Australia violated rights of Deaf people over jury service - UN experts. Retrieved from http://un.org.au/2016/04/27/australia-violated-rights-of-Deaf-people-over-jury-service-un-experts/

United Nations (UNCRPD). (2006). Convention on the rights of persons with disabilities.. Retrieved from http://www.un.org/disabilities/convention/conventionfull.shtml

Woodward, J. (1972). Implications for sociolinguistic research among the Deaf. Sign Language Studies, 1(1), 1-7. https://doi.org/10.1353/sls.1972.0004

World Health Organization. (2018). Deafness and hearing loss.. Retrieved from http://www.who.int/mediacentre/factsheets/fs300/en/

Wulfhorst, J. D., Eisenhauer, B. W., Gripne, S. L., \& Ward, J. M. (2008). Core criteria and assessment of participatory research. In C. Wilmsen, W. Elmendorf, L. Fisher, J. Ross, B. Sarathy, \& G. Wells (Eds.), Partnerships for empowerment: Participatory research for community-based natural resource management. London: Earthscan (pp. 23-46).

Young, A., Monteiro, B., \& Ridgeway, S. (2000). Deaf people with mental health needs in the criminal justice system: a review of the UK literature. The Journal of Forensic Psychiatry, 11(3), 556-570. https://doi.org/10.1080/09585180010004810

Young, A., \& Temple, B. (2014). Approaches to social research: The case of deaf studies. Perspectives on Deafness. New York, NY: Oxford University Press.

Schwartz, Michael. (2019). "What's the CRAIC?" Health Care for Deaf People in Northern Ireland Vol. 35: No. 1 , Article 19. Available at:. Touro Law Review, 35(1), 481-522 [article number: 19] https://digitalcommons.tourolaw.edu/lawreview/vol35/iss1/19.

Eades, D., \& Pavlenko, A. (2017). Translating Research into Policy: New Guidelines for Communicating Rights to Non-Native Speakers. Language and Law: Linguagem e Direito, 3(2), 45-52 (Retrieved from http://ojs.letras.up.pt/index.php/LLLD/article/view/1752). 
Elder, Brent, C., \& Schwartz, Michael, A. (2018). Effective deaf access to justice. Journal of Deaf Studies and Deaf Education, 23(4), 331-340 [https://doi.org/10.1093/deafed/eny023].

Schwartz, Michael, A., \& Elder, Brent, C. (2018). Deaf Access to Justice in Northern Ireland: Rethinking “Reasonable Adjustment” in the Disability Discrimination Act. Disability E'Society, 33(7), 1003-1024. https://doi.org/10.1080/09687599.2018.1478801

Byrne, Bronagh, Elder, Brent, C., \& Schwartz, Michael, A. (2021). Enhancing deaf people's access to justice: Implementing Article 13 of the UN Convention on the Rights of Persons with Disabilitiesd. Scandinavian Journal of Disability Research, 23(1), 74-84 [http://doi.org/10.16993/sjdr.744]. 